\title{
Diversity of epiphytic fungi on the diseased and healthy leaves of Bambusa
}

\author{
Shujiang Li ${ }^{1}$, Yan Peng ${ }^{1}$, Tianhui Zhu ${ }^{1,2 \star}$, Hanmingyue $\mathrm{Zhu}^{3}$, Cui Mao ${ }^{1}$ and Tianmin Qiao ${ }^{1}$ \\ ${ }^{1}$ College of Forestry, Sichuan Agricultural University, Ya'an, Sichuan, China. \\ ${ }^{2}$ Key Laboratory of Forest Protection of Sichuan Province, Sichuan Agricultural University, Ya'an, Sichuan, China. \\ ${ }^{3}$ Department of Foreign Affairs Administration, Chengdu Institute, Sichuan International Studies University, Chengdu, \\ Sichuan, China.
}

Accepted 20 December, 2012

\begin{abstract}
Based on the sampling on permanent sample plots in different seasons, quantities of epiphytic fungi, seasonal changes of fungal species, fungal community composition, and the relationship of epiphytic fungi and microenvironment of Bambusa pervariabilis $\times$ Dendrocalamopisis grandis were studied by plate dilution, morphological and molecular biological methods. The above four aspects were also comparatively analyzed between healthy leaves and diseased leaves. The results show that quantities of epiphytic fungi in diseased leaves was more than those of healthy leaves; fungal species was at most in summer and autumn and the isolation rate of Fusarium avenaceum and Microdochium sp. 3 was higher than the others. Diversity index of fungi in different kinds of leaves indicated they had different richness and evenness degrees. Physiological index showed that the correlation was significant between epiphytic fungi quantities on diseased leaves and content of soluble protein, and had a significant positive correlation between fungal quantities in healthy leaves and content of soluble sugar.
\end{abstract}

Key words: Bambusa pervariabilis $\times$ Dendrocalamopisis grandis, diversity index, fungi, physiological index.

\section{INTRODUCTION}

Pathogen, host and environment are three basic factors in plant disease, among them, the pathogen and the host are a pair of the basic contradictions, and the direction of development mainly depends on the condition of pathogen and host plant. The microenvironment of the host individual, microbial populations, as well as the target microorganisms (pathogens, subaltern pathogens, asymptomatic pathogens) may have a major impact. Microbial populations and diversity of change can cause the imbalance of micro-ecological balance of the host plants. In the normal plant, the type and quantity of the pathogen is controlled at a certain level, and it does not cause disease. Once other factors change, it may cause disease that the population and quantity of the pathogen increases to a certain extent. Therefore, adjusting and controlling micro-ecological environment to make the

\footnotetext{
*Corresponding author. E-mail: zhutianhui@yahoo.cn; zhuth1227@tom.com. Tel: 086-835-2882335.
}

balance of ratio between normal microorganisms and pathogens is extremely important in the control of the occurrence and development of plant disease.

All fungi living in the trees, including a variety of fungi in living or dead tissue and organ, are the important components of forest microorganisms (Myers et al., 2001). But for a long time, the study of plant fungus was more concentrated in the endogenous fungus. Hyde et al. (1997) studied comprehensively the endogenous fungus of palm trees Trachycarpus sp. in Australia's tropical regions, and pointed out that about 100 species of endogenous fungi could be separated from each palm tree. The report by Arnold et al. (2000) claimed that leaves of trees in tropical rainforest contained very rich endogenous fungus. When Estela et al. (2005) researched the endogenous fungi in the leaves of the lemon Citrus limon in northwest Argentina orchard, they found that endogenous fungi were detected in almost all the leaves. Cannon and Simmons (2002) found 64 morphological species from separation and identification of endogenous fungi in leaves of 12 plants of trees in the protected forest areas of Guyana. 
Moreover, the study of plant fungus also focused on the antagonistic action of a particular species. Separation of endogenous fungus of cacao by Rubini et al. (2005), obtained one fungus (Gliocladium catenulatum) which reduced the incidence of witches' broom disease in cacao seedlings to $70 \%$. A fungal strain of endogenous fungi Trichoderma harzianum was gotten through separation and filtration in Chinese holly by Shi et al. (2009), which had different degrees of inhibition to mycelial growth of nine kinds of plant pathogenic fungi and spore germination of two kinds of plant pathogenic fungi. A bacterial strain of endogenous fungi Pestalotiopsis sp. was gotten through separation from leaves of pyrethrum by $\mathrm{Yi}$ et al. (2008); had an inhibition more than $85 \%$ to 6 kinds of pathogenic fungi such as Glomerella cingulata, Botrytis cinerea and Exerohilum turcicum.

Bambusa pervariabilis $\times$ Dendrocalamopisis grandis is an excellent economic bamboo species, and the information about microbial ecological diversity of the leaves of this bamboo has not been reported until now. In this paper, targeted micro-environment of the hybrid bamboo leaves and their endogenous fungi were studied, as well as the quantities and population of the epiphytical fungi of the diseased and healthy leaves and their correlation with the physiological index were analyzed whose aim was to provide theoretical and practical evidences for the further studies on the biological prevention and ecological regulation of the disease of branch and leaf.

\section{MATERIALS AND METHODS}

Leaf samples of $B$. pervariabilis $\times D$. grandis were respectively collected in September 2008 (autumn), December 2008 (winter), March 2009 (spring), and June 2009 (summer) in Yaoqiao town of Ya'an City. Relatively healthy hybrid bamboo area (100 acres) where plants not with disease accounted for $80 \%$ and plants with disease accounted for $20 \%$ (wilting) was selected. The sample plot was divided into three zones; 10 plants of $B$. pervariabilis $\times D$. grandis were randomly selected in each zone, and 36 leaves were collected from each plant through dividing each plant into upper, middle and lower layer and three leaves were collected in the east, south, west and north each layer. The leaves in the sterile bags were brought back to the laboratory and were stored at $4^{\circ} \mathrm{C}$, then fungal isolation from leaf samples was done within $12 \mathrm{~h}$.

\section{Culture medium}

Potato dextrose agar (PDA) medium (Nielsen and Sørensen 1997) (potato $200 \mathrm{~g}$, glucose $20 \mathrm{~g}$, agar $20 \mathrm{~g}$, distilled water $1,000 \mathrm{ml}$ with $\mathrm{pH} 7.0$ ), and $250 \mathrm{mg}^{-1}$ streptomycin was added when it was used.

\section{Isolation, purification and preservation of fungi}

Five holes (each hole with the diameter of $1 \mathrm{~cm}$ ) were randomly punched on each leaf, healthy leaves and diseased leaves were respectively placed in a flask containing $100 \mathrm{ml}$ of sterile water, and fungi were separated using plate dilution method after oscillating for $1 \mathrm{~h}$ in the oscillator of constant temperature of $25^{\circ} \mathrm{C}$ (Harris and Sommers, 1968). Then, fungi were cultured at $25-28^{\circ} \mathrm{C}$ for $2-3$ days; counted using plate count method.

\section{Identification of fungi}

The major identification of fungi referred to the "Fungi identification manual" (Wei, 1979) describing the fungal colony morphology, and it conducted fungal microstructure observation and identified segregative fungi to the genus. ITS region of rDNA sequence was used to analyze predominant strains: (1) extraction of DNA: culture medium that was inoculated with fresh fungi for 3-4 days on shaker at constant temperature $\left(28^{\circ} \mathrm{C}, 125 \mathrm{r} \cdot \mathrm{min}^{-1}\right)$ was filtered with doublelayer sterile gauze to collect the mycelium, and it was washed by sterile water and squeezed by filter paper. The mycelium set into mortar was quickly ground into power after liquid nitrogen was added, then it was collected to a $2 \mathrm{ml}$ centrifuge tube. DNA was extracted by TIANamp Plant DNA Kit of plant genomic DNA extraction kit (centrifugal columnar) and it was stored at $-20^{\circ} \mathrm{C}$; (2) PCR amplification reaction: the primer sequences were ITS1: 5'TCC GTA GGT GAA CCT GCG G-3' and ITS: 5'-TCC TCC GCT TAT TGA TAT GC-3', and they were respectively used to amplified ITS and 5.8 SrDNA. ITS included ITS1 between the 18S and 5.8S rDNA and ITS4 between $5.8 \mathrm{~S}$ and $28 \mathrm{~S}$ rDNA. Total PCR reaction system was $50 \mu \mathrm{l}$, including template $2 \mu \mathrm{l}$, primer ITS1 $2 \mu \mathrm{l}$, primer ITS4 $2 \mu \mathrm{l}$, 2×TCP PCR master mix $25 \mu \mathrm{l}$, deionized water $19 \mu \mathrm{l}$, and a blank control was set. The reaction conditions were $95^{\circ} \mathrm{C}$ initial denaturation for $5 \mathrm{~min}, 95^{\circ} \mathrm{C}$ for $1 \mathrm{~min}, 50^{\circ} \mathrm{C}$ for $1 \mathrm{~min}, 72^{\circ} \mathrm{C}$ for 1 min for 30 cycles, then $72^{\circ} \mathrm{C}$ extended for $5 \mathrm{~min}$ and stored at $4^{\circ} \mathrm{C}$; (3) Electrophoresis: $5 \mu$ of PCR products was done on $1.5 \%$ agarose gel by electrophoresis, which was dyed with ethidium bromide (EB), under $80 \mathrm{~V}$ for $30 \mathrm{~min}$. The size of PCR product was detected through UV observation of gel imaging system and scanning photograph; (4) DNA sequencing: the PCR products were sent to Shanghai Sangon Biotechnology Company for DNA sequencing, and homology comparison between the sequence measured and the sequence that had been reported in GenBank database through the Internet (http://www.ncbi.nlm.nihgov/blast.cgi) to determine the status of the test fungi in the microbial phylogeny.

\section{Determination of physiological index of leaves}

The $\mathrm{pH}$ value was determined by $744 \mathrm{pH}$ acidimeter (Beijing Tayasaf Science and Technology co., LTD, China). Soluble protein content was determined through coomassie brilliant blue G250 method and bovine serum albumin (BSA) was taken as the control, and soluble sugar content was assessed by anthrone method (Ludwig, 1956).

\section{Statistical analysis}

The dominant flora was comparatively determined by the isolation frequency (IF); IF: strains of a certain specified type of fungi isolated accounted for the percentage of the strains of the total number of fungi isolated. The richness of fungi in plant tissue was measured by the isolation rate (IR); IR: strains of a certain specified type of fungi isolated accounted for the percentage of the total number of isolated samples.

Shannon-Wiener index $(\mathrm{H})$ and Simpson index $(\mathrm{D})$ were used to analyze the biodiversity of fungal communities. $\mathrm{H}=-\Sigma(\mathrm{Pi})(\ln \mathrm{Pi})$, $\mathrm{D}=1-\Sigma(\mathrm{Pi})^{2}$, where $\mathrm{Pi}$ was the proportion of individuals belonging to species $\mathrm{i}$ in all individuals; Evenness index $(\mathrm{J})$ was used to analyze the uniformity of species distribution. $\mathrm{J}=\mathrm{H} / \mathrm{InS}$, where, $\mathrm{H}$ was the Shannon-wiener index and $\mathrm{S}$ was the total number of species.

All data were subjected to one-way analysis of variance to determine the significance of individual differences at $P<0.05$ and $P<$ 0.01 levels. Significant means were compared using the LSD test. All statistical analyses were conducted using the SPSS commercial statistical package (SPSS, Version 17.0 for Windows, SPSS Inc. Chicago, USA). 


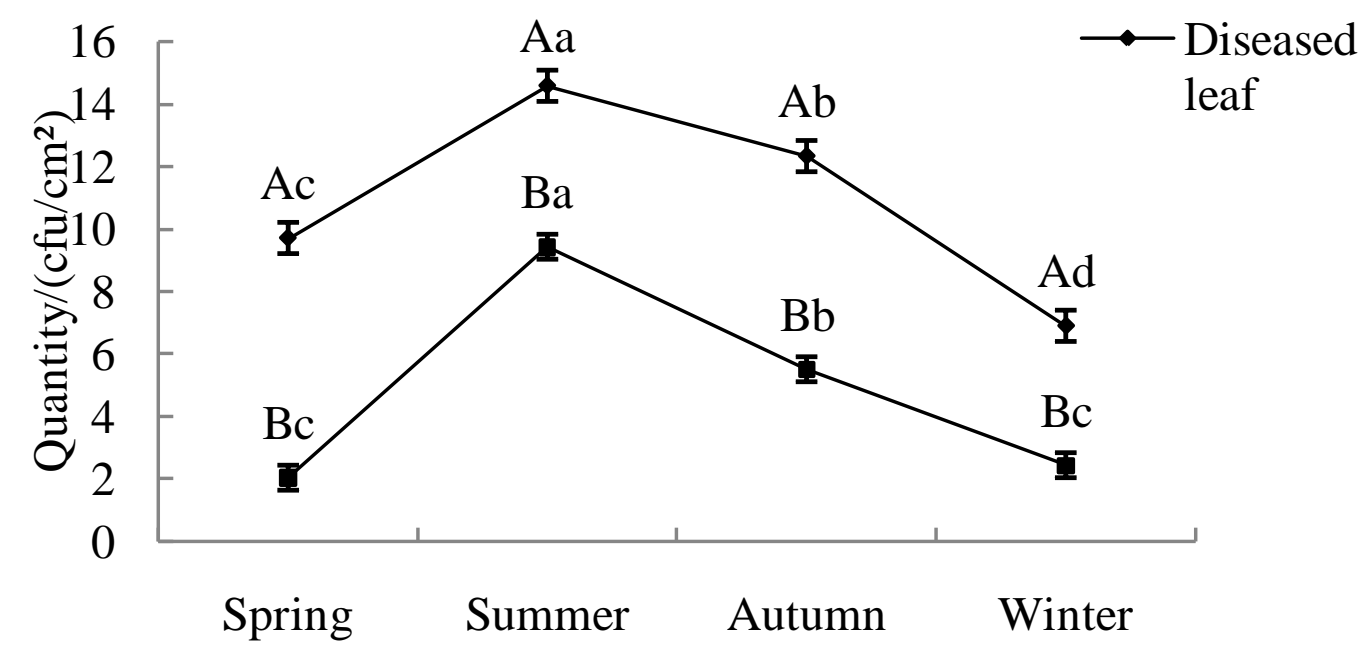

Season

Figure 1. Seasonal changes of the number of epiphytic fungi of healthy leaves and diseased leaves of $B$. pervariabilis $\times D$. grandis. Different capital letters indicate significant differences between healthy leaves and diseased leaves in the same season by the LSD test $(P<0.05)$; different lowercase letters indicate significant differences among different seasons of the same type of leaves by the LSD test $(P<0.05)$.

\section{RESULTS}

\section{Seasonal dynamic changes of the quantity of epiphytic fungi}

For health and diseased leaves of $B$. pervariabilis $\times D$. grandis, seasonal dynamic changes of the number of fungi (Figure 1) showed that for both healthy leaves and diseased leaves, the number of epiphytic fungi were summer $>$ autumn $>$ spring $\approx$ winter, and the decline was sharp from summer to autumn; the number of epiphytic fungi of diseased leaves were greater than the healthy leaves in the four seasons of the year, and the difference was significant. Seen from diseased leaves, the quantity variance among each season reached to a significant level $(P<0.05)$; the difference of the number of epiphytic fungi of healthy leaves was not significant in spring and winter, and the rest of the season was significant.

\section{Species of epiphytic fungi}

Through isolation and identification, there were 31 species of epiphytic fungi on the surface of hybrid bamboo's leaves, with 18 species of epiphytic fungi on healthy leaves and 20 species of epiphytic fungi on diseased leaves and two strains could not be identified (3Jb4, 3Bb23) (Table 1). There was one species of epiphytic fungus on the surface of healthy leaves that appeared in two seasons, accounting for $5.56 \%$; and there were 17 species of epiphytic fungi that appeared only in one season, accounting for $94.45 \%$. That is, most of the fungi only occurred in one season. 3 species of fungi were isolated from the surface of healthy leaves in the spring, and the relative isolation frequency of two species named Perenniporia sp. 3 (37.21\%), and Arthrinium sp. 2 (11.63\%) reached 10\%; 5 dominant species of fungi were isolated in summer; 13 species of fungi were isolated in the autumn, and Pleosporales sp. 1 (44.00\%) was the dominant species; six species of fungi were isolated in winter, and dominant species included Perenniporia medulla-panis (35.29\%), Phaeospheria setosa, Fusarium sp. (11.76\%) and Gibberella sp. (23.53\%). On the surface of healthy leaves, there were 12 dominant species. They mostly appeared in one season and performed the activity peak with the largest number in the summer.

There was one species of epiphytic fungus on the surface of diseased leaves appearing in three seasons, accounting for $5 \%$ of the number of isolated fungal species; and there were four species of epiphytic fungi appearing in two seasons, accounting for $20 \%$, and besides, there were 15 kinds of epiphytic fungi appearing in one season, accounting for $75 \%$. 10 species of fungi were isolated from the surface of diseased leaves in spring, and among them there were two dominant species named Lacazia loboi (23.63\%) and Truncatella sp. $(32.72 \%)$; nine species of fungi were isolated in sum-mer with one dominant species named Fusarium avena-ceum $(14.13 \%)$; four species of fungi were isolated in autumn, and they were all dominant fungi expect Lacazia loboi; 14 species of fungi were isolated in the winter, and 
Table 1. Composition and season succession of epiphytical fungi on leaves of $B$. pervariabilis $\times D$. grandis.

\begin{tabular}{|c|c|c|c|c|c|c|c|c|c|c|c|c|}
\hline \multirow{3}{*}{ Specie } & \multicolumn{2}{|c|}{ Information in NCBI GenBank } & \multicolumn{10}{|c|}{ Relative isolation frequency $/ \%$} \\
\hline & \multirow{2}{*}{ Accession } & \multirow{2}{*}{ Identity index (\%) } & \multicolumn{5}{|c|}{ Healthy leaves } & \multicolumn{5}{|c|}{ Diseased leaves } \\
\hline & & & Spring & Summer & Autumn & Winter & Mean & Spring & Summer & Autumn & Winter & Mean \\
\hline Fusarium equiseti & FJ459976.1 & 100 & 0.00 & 0.00 & 8.00 & 0.00 & 2.00 & 0.00 & 0.0 & 0.00 & 0.00 & 0.00 \\
\hline Apiospora montagnei & FJ228174.1 & 99 & 0.00 & 0.00 & 8.00 & 0.00 & 2.00 & 0.00 & 0.00 & 0.00 & 0.00 & 0.00 \\
\hline Fusarium sp.1 & JX401981.1 & 99 & 0.00 & 0.00 & 4.00 & 0.00 & 1.00 & 0.00 & 0.00 & 0.00 & 0.00 & 0.00 \\
\hline Coprinellus radians & FJ462761.1 & 99 & 0.00 & 0.00 & 4.00 & 0.00 & 1.00 & 0.00 & 0.00 & 0.00 & 0.00 & 0.00 \\
\hline Ascomycete sp. & AJ279473.1 & 99 & 0.00 & 0.00 & 4.00 & 0.00 & 1.00 & 0.00 & 0.00 & 0.00 & 0.00 & 0.00 \\
\hline Perenniporia medulla-panis & FJ627262.1 & 99 & 0.00 & 0.00 & 8.00 & 35.29 & 10.82 & 0.00 & 0.00 & 0.00 & 0.00 & 0.00 \\
\hline Aureobasidium pullulans & DQ534409.1 & 99 & 0.00 & 0.00 & 4.00 & 0.00 & 1.00 & 0.00 & 0.00 & 0.00 & 0.00 & 0.00 \\
\hline Gibberella avenacea & FJ614645.1 & 99 & 0.00 & 0.00 & 8.00 & 0.00 & 2.00 & 0.00 & 0.00 & 0.00 & 6.06 & 1.52 \\
\hline Cladosporium sp. & EF120415.1 & 100 & 0.00 & 0.00 & 8.00 & 0.00 & 2.00 & 0.00 & 0.00 & 0.00 & 0.00 & 0.00 \\
\hline Perenniporia sp.1 & JQ348934.1 & 100 & 0.00 & 0.00 & 4.00 & 0.00 & 1.00 & 0.00 & 0.00 & 0.00 & 0.00 & 0.00 \\
\hline Pleosporales sp.1 & AB255305.1 & 98 & 0.00 & 0.00 & 44.00 & 0.00 & 11.00 & 0.00 & 0.00 & 0.00 & 0.00 & 0.00 \\
\hline Phoma sp. & EF600958.1 & 100 & 0.00 & 0.00 & $4 . .00$ & 0.00 & 1.00 & 0.00 & 0.00 & 0.00 & 0.00 & 0.00 \\
\hline Aspergillus fumigatus & EU314992.1 & 100 & 0.00 & 0.00 & 4.00 & 0.00 & 1.00 & 0.00 & 0.00 & 0.00 & 0.00 & 0.00 \\
\hline Acremonium strictum & AY138848.1 & 99 & 0.00 & 0.00 & 0.00 & 0.00 & 0.00 & 0.00 & 0.00 & 58.33 & 4.04 & 15.59 \\
\hline Doratomyces stemonitis & EF029213.1 & 99 & 0.00 & 0.00 & 0.00 & 0.00 & 0.00 & 0.00 & 0.00 & 16.67 & 0.00 & 4.17 \\
\hline Aspergillus versicolor & AY373883.1 & 99 & 0.00 & 0.00 & 0.00 & 0.00 & 0.00 & 0.00 & 0.00 & 16.67 & 0.00 & 4.17 \\
\hline Lacazia loboi & FJ037740.1 & 99 & 0.00 & 0.00 & 0.00 & 0.00 & 0.00 & 23.63 & 41.30 & 8.33 & 0.00 & 18.32 \\
\hline Septogloeum mori & EU520242.1 & 100 & 0.00 & 0.00 & 0.00 & 5.89 & 1.47 & 0.00 & 0.00 & 0.00 & 0.00 & 0.00 \\
\hline Phaeospheria setosa & AF439500.1 & 99 & 0.00 & 0.00 & 0.00 & 11.76 & 2.94 & 0.00 & 0.00 & 0.00 & 0.00 & 0.00 \\
\hline Anthostomella sp. & JQ754113.1 & 99 & 0.00 & 0.00 & 0.00 & 5.89 & 1.47 & 0.00 & 0.00 & 0.00 & 0.00 & 0.00 \\
\hline Fusarium sp.2 & JX401969.1 & 100 & 0.00 & 0.00 & 0.00 & 11.76 & 2.94 & 0.00 & 0.00 & 0.00 & 0.00 & 0.00 \\
\hline Gibberella sp. & AY188925.1 & 99 & 0.00 & 0.00 & 0.00 & 23.53 & 5.88 & 0.00 & 0.00 & 0.00 & 0.00 & 0.00 \\
\hline Botryosphaeria sp. & JX139940.1 & 99 & 0.00 & 0.00 & 0.00 & 0.00 & 0.00 & 0.00 & 0.00 & 0.00 & 8.08 & 2.02 \\
\hline Fusarium avenaceum & JX398940.1 & 99 & 0.00 & 0.00 & 0.00 & 0.00 & 0.00 & 0.00 & 14.13 & 0.00 & 36.36 & 12.62 \\
\hline Arthrobotrys foliicola & U51954.1 & 98 & 0.00 & 0.00 & 0.00 & 0.00 & 0.00 & 0.00 & 1.09 & 0.00 & 5.05 & 1.54 \\
\hline Arthrinium sacchari & AB470880.1 & 98 & 0.00 & 0.00 & 0.00 & 0.00 & 0.00 & 0.00 & 0.00 & 0.00 & 2.02 & .0 .51 \\
\hline Pestalotiopsis microspora & DQ001002.1 & 100 & 0.00 & 0.00 & 0.00 & 0.00 & 0.00 & 0.00 & 0.00 & 0.00 & 1.01 & 0.25 \\
\hline Microdochium sp.1 & AM502258.1 & 99 & 0.00 & 0.00 & 0.00 & 0.00 & 0.00 & 0.00 & 0.00 & 0.00 & 1.01 & 0.25 \\
\hline Microdochium nivale & EF187912.1 & 99 & 0.00 & 0.00 & 0.00 & 0.00 & 0.00 & 0.00 & 0.00 & 0.00 & 3.03 & 0.76 \\
\hline Aspergillus sp.1 & JX277550.1 & 100 & 0.00 & 0.00 & 0.00 & 0.00 & 0.00 & 0.00 & 0.00 & 0.00 & 4.04 & 1.01 \\
\hline Microdochium sp.2 & GU934541.1 & 98 & 0.00 & 0.00 & 0.00 & 0.00 & 0.00 & 0.00 & 0.00 & 0.00 & 2.02 & 0.51 \\
\hline Aspergillus sp.2 & JX136721.1 & 99 & 0.00 & 0.00 & 0.00 & 0.00 & 0.00 & 0.00 & 0.00 & 0.00 & 3.03 & 0.76 \\
\hline Microdochium phragmitis & AJ279449.1 & 99 & 0.00 & 0.00 & 0.00 & 0.00 & 0.00 & 0.00 & 0.00 & 0.00 & 2.02 & 0.51 \\
\hline Fusarium sp.3 & JX397803.1 & 99 & 0.00 & 0.00 & 0.00 & 0.00 & 0.00 & 0.00 & 0.00 & 0.00 & 3.03 & 0.76 \\
\hline
\end{tabular}


Table 1. Contd.

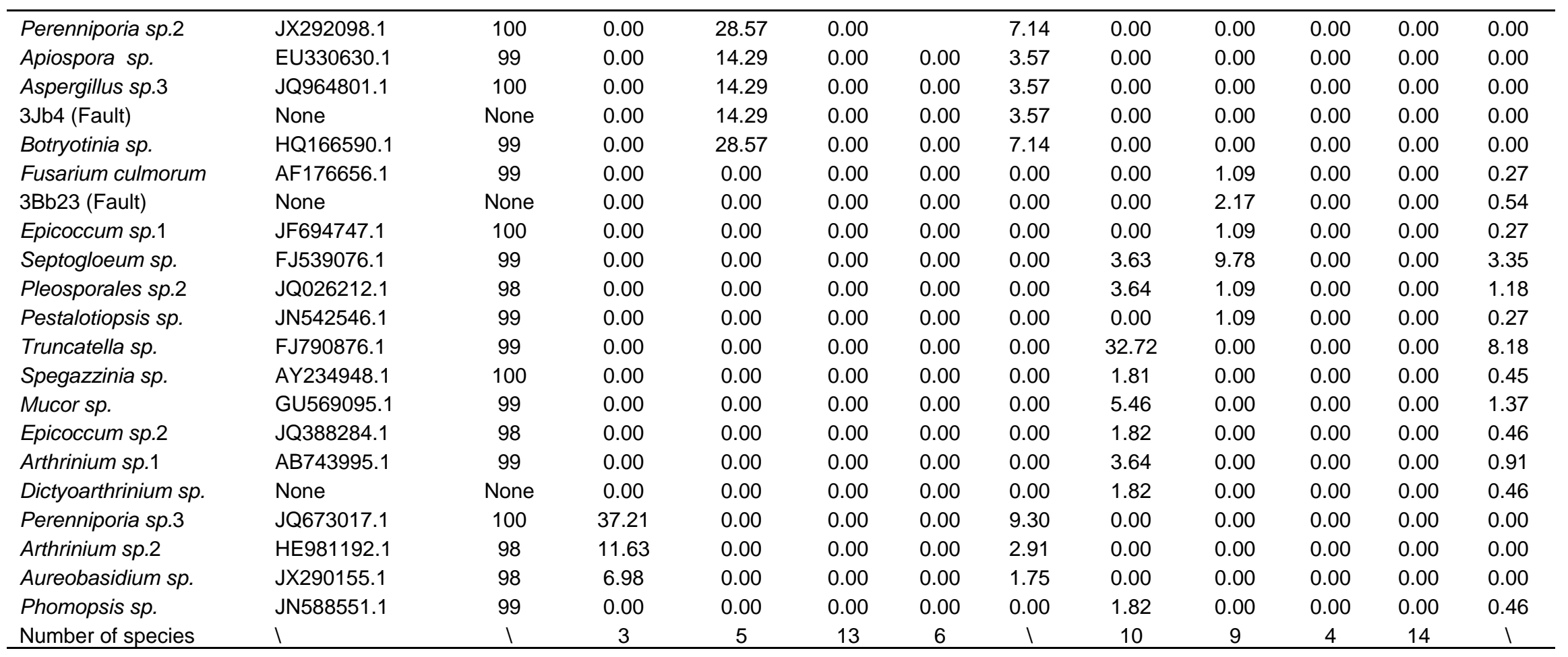

Fusarium avenaceum (34.36\%) was the dominant species. Only Fusarium avenaceum was dominant in two seasons, and other species were only dominant in one season. Comparing healthy leaves with diseased leaves, the difference of their dominant species was significant. The dominant fungi on the surface of healthy leaves were not dominant on the surface of diseased leaves, and the reverse was also true.

\section{Species richness of the epiphytic fungi}

The results of seasonal dynamic changes of species richness of epiphytic fungi (Figure 2) showed that the tendency of species richness of epiphytic fungal groups of the healthy leaves from high to low was as follow: autumn> winter> summer> spring, and that of the diseased leaves was the same. Species richness of epiphytic fungal groups on the surface of healthy leaves was higher than that of diseased leaves only in autumn, and the difference between them was most obvious in summer followed by autumn, and it was the smallest in the spring.

The results of variance analysis (Table 2) showed that the relationship between species richness and seasonal variation of epiphytic fungi was significant, but the relationship between species richness and leaves types was not significant.

\section{Diversity of epiphytic fungi}

The results of diversity index of epiphytic fungi are showed in Table 3. The Shannon-Wiener index of epiphytic fungal groups of healthy leaves was highest in autumn (2.1426). Simpson index ranged from $0-1$, and the result was the same with Shannon-Wiener index with the value of 0.8112 . Evenness could reflect the uniformity of the distribution of different species in the community.

Through the calculation of evenness index for each fungal flora, it was found that evenness of 


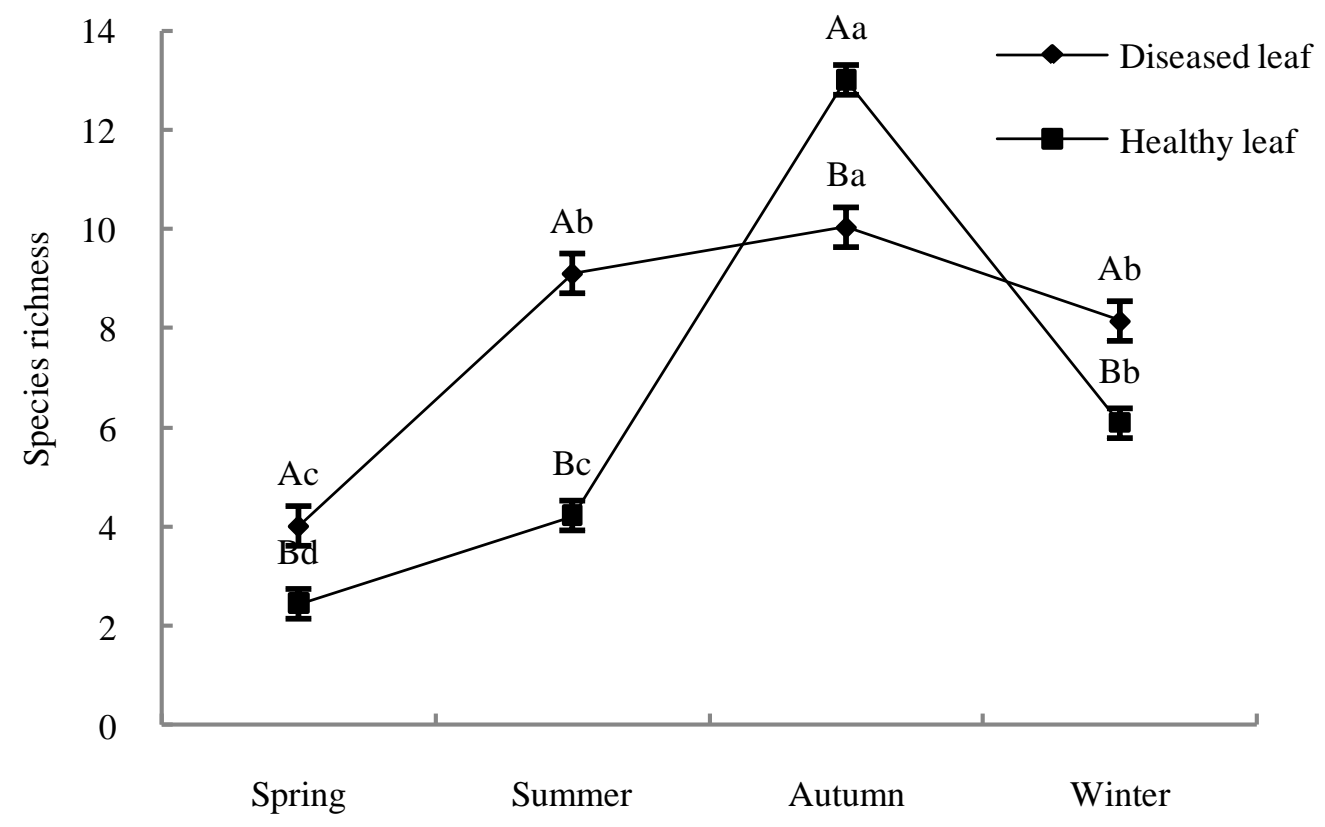

Season

Figure 2. Change of species richness of epiphytic fungi of healthy leaves and diseased leaves of $B$. pervariabilis $\times D$. grandis. Different capital letters indicate significant differences between health leaves and diseased leaves in the same season by the LSD test $(P<0.05)$; different lowercase letters indicate significant differences among different seasons of the same type of leaves by the LSD test $(P<0.05)$.

Table 2. Analysis of variance on fungal species richness of different leaves and seasons.

\begin{tabular}{lcccccc}
\hline $\begin{array}{l}\text { Dependent } \\
\text { variable }\end{array}$ & $\begin{array}{c}\text { Source of } \\
\text { variable }\end{array}$ & $\begin{array}{c}\text { Standard deviation } \\
\text { square (SS) }\end{array}$ & $\begin{array}{c}\text { Degree freedom } \\
\text { (df) }\end{array}$ & $\begin{array}{c}\text { Mean square } \\
\text { (MS) }\end{array}$ & $\begin{array}{c}\text { F } \\
\text { value }\end{array}$ & $\begin{array}{c}\text { Significance } \\
\text { level }\end{array}$ \\
\hline \multirow{2}{*}{ Epiphytic fungi } & Type of leaf & 10.125 & 1 & 10.125 & 0.968 & 0.398 \\
& Season & 77.375 & 3 & 25.792 & $2.466^{*}$ & 0.023 \\
\hline
\end{tabular}

*indicates that correlation is significant by the LSD test $(P<0.05)$.

were mostly above 0.6 . Evenness degree index of epiphytic fungal flora of the diseased leaves was highest in spring with the value of 1 .

\section{Relationship between epiphytic fungal diversity and physiological index}

The number of fungi was not only influenced by season and type of leaves, but also by the microenvironment of the leaves. This microenvironment mainly referred to the $\mathrm{pH}$, protein content and soluble sugar content. These indexes that provide nutrient sources for fungal survival are shown in Table 4. The results show that the correlation between epiphytic fungi of diseased leaves and protein content was significant; the correlation between epiphytic fungi of healthy leaves and soluble sugar content was highly significant. Carbohydrates were the survival nutrition resources of the fungi, which illustrated that the sugar and fungal growth were inseparable from ano- ther side.

\section{DISCUSSION}

The results presented in the current study show that no whether they were diseased leaves or healthy leaves, the number of epiphytic fungi reached the peak values in summer and autumn, and the fluctuation range of diseased leaves was greater than that of healthy leaves. This may be that leaves fully developed or matured in summer, and surface area of leaves increased, and the nutrients such as pollen, and aphid honeydew, also increased. As a result, original epiphytic fungi gradually grew and expanded or they had more opportunity to infect the leaves. On the other hand, there was a subtropical humid monsoon climate in Ya'an. Except cold mountain area, generally, it was not cold in the winter, not hot in the summer, and it was warm and dry in spring, besides, the rainfall concentrated in summer, and there was more rain at 
Table 3. Diversity index of fungi in leaves of $B$. pervariabilis $\times D$. grandis.

\begin{tabular}{|c|c|c|c|c|c|}
\hline \multirow{2}{*}{ Type of leaf } & \multirow{2}{*}{ Season } & \multirow{2}{*}{$\begin{array}{l}\text { Number of } \\
\text { species }\end{array}$} & \multicolumn{2}{|c|}{ Diversity index } & \multirow{2}{*}{ Evenness } \\
\hline & & & Shannon-Wiener index & Simpson index & \\
\hline \multirow{4}{*}{ Healthy leaf } & Spring & 3 & $0.8571^{d}$ & $0.4966^{\mathrm{e}}$ & $0.7802^{d}$ \\
\hline & Summer & 5 & $1.5499^{b}$ & $0.7755^{\mathrm{a}}$ & $0.9630^{\mathrm{a}}$ \\
\hline & Autumn & 13 & $2.1426^{a}$ & $0.8112^{\mathrm{a}}$ & $0.8353^{\mathrm{C}}$ \\
\hline & Winter & 6 & $1.5810^{\mathrm{b}}$ & $0.7579^{a b}$ & $0.8824^{b}$ \\
\hline \multirow{4}{*}{ Diseased leaf } & Spring & 10 & $1.6320^{\mathrm{b}}$ & $0.7351^{\mathrm{b}}$ & $0.7088^{\mathrm{e}}$ \\
\hline & Summer & 9 & $1.3286^{b c}$ & $0.6207^{\mathrm{c}}$ & $0.6047^{f}$ \\
\hline & Autumn & 10 & $1.1188^{\mathrm{C}}$ & $0.5972^{d}$ & $0.4859^{9}$ \\
\hline & Winter & 14 & $2.0123^{\mathrm{a}}$ & $0.7666^{\mathrm{a}}$ & $0.7625^{d}$ \\
\hline
\end{tabular}

Data followed by different lowercase letters in the same row indicate significant differences by the LSD test $(P<0.05)$.

Table 4. Correlation between epiphytic fungal diversity and physiological index.

\begin{tabular}{lccc}
\hline \multirow{2}{*}{ Type of leaf } & \multicolumn{3}{c}{ Correlation coefficient } \\
\cline { 2 - 4 } & $\mathbf{p H}$ & Soluble protein & Soluble sugar \\
\hline Healthy leaf & 0.359 & 0.563 & $0.998^{\star *}$ \\
Diseased leaf & 0.189 & $0.955^{\star}$ & 0.418 \\
\hline
\end{tabular}

*Indicates that correlation was significant by the LSD test $(P<0.05)$; ** indicates that correlation was significant by the LSD test $(P<0.01)$.

night. Annual average temperature of the sample plot was $16.2^{\circ} \mathrm{C}$ with $6.1^{\circ} \mathrm{C}$ in January and $25.4^{\circ} \mathrm{C}$ in July. Temperature in July was particularly suitable for the fungal growth, therefore, the number of fungi significantly increased in summer and autumn, which was similar to the result achieved by Du et al. (2009).

In terms of the species of epiphytic fungi, richness reached the peak value in summer and autumn, and the dominant species in these two seasons were obviously different from the other seasons which indicated that the richness level might be related to the characteristics of epiphytic fungi, besides the size of the surface area of leaves and the environment of the sample plot. Microdochium sp. was dominant in summer and autumn, which is in agreement with the conclusion of Hiilovaara-Teijo et al. (1999). PR protein induced by Microdochium nivale did not have resistance against the cold, so the number of Microdochium sp. gradually reduced in the cold winter and its advantage was gradually not obvious. Moreover, Fusarium sp. appeared in summer and winter and it was the dominant species, which was inseparable from the wide distribution of Fusarium sp.: it was commonly found in soil and organisms of animals and plants, even in the cold Arctic and the hot arid desert.

Fusarium is one genus fungi of worldwide distribution, and it can infect a variety of plants (food crops, cash crops, medicinal plants and ornamental plants), causing many plant diseases such as rot of root, stem, stem base, flower and ear. It also can infect the vascular system, destruct the vascular bundle of plant conducting tissue and produce toxins harming crops in the process of growth and metabolism, making crops wilt and die. It was one important disease that was difficult for control and cure in production. Therefore, this pathogen was likely the main factor which makes local hybrid bamboo to be susceptible. In addition, eight species of fungi on healthy leaves were not isolated from diseased leaves, and 12 species of fungi on diseased leaves were not isolated from healthy leaves, and the dominant fungi on healthy were not dominant on diseased leaves. In order to establish a more perfect hybrid bamboo biological control theory, these fungi need more in-depth research.

The indexes of richness and evenness are important factors to reflect the distribution of the fungal groups in habitat. It indicated that species would be more and diversity would be higher while the value of richness index was greater. Diversity index calculated from this study can infer that the epiphytic fungal flora on healthy leaves had high diversity in the autumn. Result reflected by the diversity indexes obtained from Shannon-Wiener index was consistent with Simpson index. The evenness index showed that the diversity of fungi in this study was relatively stable and distribution of flora composition was relatively homogeneous.

Fungal growth cannot be separated from the carbon and nitrogen sources. Wang et al. (2007) confirmed that the endogenous fungi isolated from Dendrobium could absorb and utilize four different kinds of carbon sources in different degrees, and the addition of nitrogen source had a great effect on the growth of endogenous fungi iso- 
lated from Dendrobium. In the present study, the correlation between soluble sugar content and soluble protein content of hybrid bamboo leaves and the number of fungi was significant. Its reason is that the simple sugars and proteins are main nutrients for the fungal growth, and sugars are the main source of nutrition (Williamson and Fokkena, 1985). When the leaves are infected by the pathogens, with the increase of pathogenic fungi, the number of fungi on the diseased leaves is also increased, and the nutritional competition is fierce. Fungi start to absorb soluble protein nutrients of the leaves when sugar consumption is finished, therefore, epiphytic fungi and soluble protein content of diseased leaves are correlative. The number of epiphytic fungi on healthy leaves of hybrid bamboo is more than that of diseased leaves; this is due to the foliar nutrients that exist in the recession or the base of lamellar seta among anticlinal walls of epidermal cells, so the nutrients easily gathers. On the contrary, the diseased leaves are susceptible, the epidermal cells are damaged and the lamellar seta shed, so the nutrients easily run off. However, the relationship between the micro-environment of the leaves and the epiphytic fungi of hybrid bamboo is very complex, whether these fungi involve in or how many fungi contribute to the metabolism of leaves of hybrid bamboo need further studies.

\section{ACKNOWLEDGEMENT}

This research was supported by the National Natural Science and Technology Resources Sharing Platform of China (2005DKA21207-13).

\section{REFERENCES}

Arnold AE, Maynard Z, Gilbert GS (2000). Are tropical fungal endophytes hyperdiverse. Ecol. Lett. 3(4):267-274.

Cannon PF, Simmons CM (2002). Diversity and host preference of leaf endophytic fungi in the Iwokrama Forest Reserve, Guyana. Mycologia 94(2):210-220.

Du SK, Chen SL, Lin D, Wu MQ, Wang MX (2009). Diversity of endophytic fungi in leaves of Ginkgo biloba. Mycosystem 28(4):504511. (in Chinese).

Estela L, Durán L, Ploper D, Ramallo JC, Grandi RAP, Giancoli ACH, Azevedo JL (2005). The foliar fungal endophytes of Citrus limon in Argentina. Can. J. Bot. 83(4):350-355.

Harris RF, Sommers LE (1968). Plate-dilution frequency technique for assay of microbial ecology. Appl. Microbiol. 16(2):330-334.

Hiilovaara-Teijo M, Hannukkala A, Griffith $M$, Yu XM, PihakaskiMaunsbach K (1999). Snow-mold-induced apoplastic proteins in winter rye leaves lack antifreeze activity. Plant Physiol. 121(2):665674.

Hyde KD, Frohlich J, Taylor J (1997). Biodiversity of tropical microfungi. Hong Kong: Hong Kong University Press. pp. 141-156.

Ludwig TG (1956). The anthrone method for the determination of carbohydrates in foods and in oral rinsing. J. Dent. Res. 35(1):90-94.
Myers RT, Zak DR, White DC, Peacock A (2001). Landscape-level patterns of microbial community composition and substrate use in upland forest ecosystems. Soil Sci. Soc. Am. J. 65(2):359-367.

Nielsen P, Sørensen J (1997). Multi-target and medium-independent fungal antagonism by hydrolytic enzymes in Paenibacillus polymyxa and Bacillus pumilus strains from barley rhizosphere. FEMS Microbiol. Ecol. 22:183-192.

Rubini MR, Silva-Ribeiro RT, Pomella AWV, Maki CS, Araújo WL, dos Santos DR, Azevedo JL (2005). Diversity of endophytic fungal community of cacao (Theobroma cacao L.) and biological control of Crinipellis perniciosa, causal agent of witches' broom disease. Int. J. Biol. Sci. 1(1):24-33.

Shi YJ, Shen TX, Yu XP (2009). Identification of an endophytic fungus isolated from Llex cornuta and the biocontrol effects of its secondary metabolite. Acta Phytopathologica Sinica 4:362-367. (in Chinese).

Wang D, Jia SH, Zhang ZX, Cai YP, Lin Y (2007). Isolation and culture of an endophytic fungus associated with Dendrobium huoshanense and its effects on the growth of plantlets. J. Fungal Res. 52(2):84-88. (in Chinese).

Wei JC (1979). Fungi identification manual. Shang Hai: Shanghai Science Press. pp 1-802. (in Chinese).

Williamson MW, Fokkena NJ (1985). Phyllosphere yeasts antagonize penetration from appressoria and subsequent infection of maize leaves by Colletotrichum gramicola. Neth. J. Plant Patho1. 91(6): 265-276.

Yi XH, Feng JT, Fang XL, Li YP, Zhang X (2008). Biological characteristics and biological activity of Pestalotiopsis sp. obtained from leaf of Pyrethrum cinerariifolium Trev. Journal of Zheng Jiang University: Agriculture and Life Science 34(5): 516-524. (in Chinese). 